\title{
Oxidation of antimony (III) by amorphous iron and manganese oxyhydroxides
}

\author{
Nelson Belzile* ${ }^{*}$ Yu-Wei Chen ${ }^{1}$, Zijian Wang \\ State Key Laboratory of Environmental Aquatic Chemistry, Research Centre for Eco-Environmental Sciences, Academia Sinica, \\ P.O. Box 2871 Beijing 100085, People's Republic of China
}

Received 23 June 1999; accepted 7 April 2000

\begin{abstract}
Amorphous forms of natural and synthetic Fe oxyhydroxides and synthetic Mn oxyhydroxides were used to study the oxidation of antimonite, $\mathrm{Sb}(\mathrm{III})$, at different $\mathrm{pH}$ values. Sb species were measured by differential pulse adsorptive stripping voltametry (DPACSV). The oxidation of $\mathrm{Sb}(\mathrm{III})$ to $\mathrm{Sb}(\mathrm{V})$ was always rapid and completed after a few days following pseudo-first order rate laws. A slightly slower oxidation rate was observed at lower $\mathrm{pH}$ and was attributed to the lower stability of the oxyhydroxide compounds under mildly acidic conditions. The oxidation pseudo-first order rate of Sb(III) by natural Fe oxyhydroxides was also slower when compared to synthetic Fe compounds. This could be explained by a slight crystallinity of the natural oxides (when compared to amorphous synthetic compounds) and by their more complex chemical composition which can include adsorbed ions and organic matter. The study confirms that amorphous $\mathrm{Fe}$ and $\mathrm{Mn}$ oxyhydroxides present in natural waters and sediments can play a detoxifying role by adsorbing and oxidizing the more toxic Sb(III) into Sb(V). (C) 2001 Elsevier Science B.V. All rights reserved.
\end{abstract}

Keywords: Oxidation; Amorphous iron and manganese oxyhydroxides; Antimony

\section{Introduction}

The aim of this study is to demonstrate experimentally that $\mathrm{Sb}$ (III), the more toxic form of antimony can, be effectively oxidized into the less toxic

\footnotetext{
* Corresponding author. Present address: Department of Chemistry and Biochemistry, Laurentian University, Ramsey Lake Road, Sudbury, Ontario, Canada P3E 2C6. Tel.: +1-705-675-1151 ext. 2114; fax: +1-705-675-4844.

E-mail address: belzile@nickel.laurentian.ca (N. Belzile).

${ }^{1}$ Present address: Department of Chemistry and Biochemistry, Laurentian University, Ramsey Lake Road, Sudbury, Ontario, Canada P3E 2 C6.
}

$\mathrm{Sb}(\mathrm{V})$ by amorphous forms of $\mathrm{Fe}$ and Mn oxyhydroxides. Antimony can be introduced in the aquatic environment through natural processes such as soil weathering and volcanic activity and the average level of $\mathrm{Sb}$ in the Earth crust is lower than $1.0 \mu \mathrm{g} / \mathrm{g}$ (Boyle and Jonasson, 1973; Wedepohl, 1995). It can also get into the hydrosphere, mostly via air transport, from the combustion of fossil fuels and mining and smelting activities (Crecelius et al., 1975; Ragaini et al., 1977) and it is known that anthropogenic emissions of $\mathrm{Sb}$ exceed those from natural sources (Nriagu and Pacyna, 1988; Nriagu, 1989). Because of a variety of natural and anthropogenic sources, $\mathrm{Sb}$ can likely be introduced in the environment as volatile 
species (e.g. $\mathrm{SbH}_{3}$ ), solutes (e.g. $\left[\mathrm{SbO}_{2}\right]^{-}$) and as solids (e.g. $\mathrm{Sb}, \mathrm{Sb}_{2} \mathrm{O}_{3}$ or $\mathrm{Sb}_{2} \mathrm{O}_{5}$ ) of the different valence states (Maeda, 1994). Although the studies on $\mathrm{Sb}$ speciation are limited, it has been clearly shown that the toxicity of $\mathrm{Sb}$ species is similar to that of arsenic with $\mathrm{Sb}(\mathrm{III})$ being much more poisonous than $\mathrm{Sb}(\mathrm{V})$ (Gurnani et al., 1994). For instance, antimony compounds can react with $-\mathrm{SH}$ groups in various cellular constituents, especially enzymes, and block their activity (Maeda, 1994). Thermodynamic calculations predict a $\mathrm{Sb}(\mathrm{III}) / \mathrm{Sb}(\mathrm{V})$ ratio as low as $10^{-18}$ under oxidizing conditions (Andreae et al., 1981). However, a significant fraction of the total $\mathrm{Sb}$ measured in natural waters can be present as $\mathrm{Sb}$ (III) even under oxidizing conditions since many environmental factors such as biological activity or kinetic considerations cannot be included in the simplified thermodynamic calculations (Andreae et al., 1981; Andreae and Froelich, 1984; Middelberg et al., 1988; Cutter and Cutter, 1995). Similar reasons can explain the presence of the oxidized form $\mathrm{Sb}(\mathrm{V})$ in reducing sediment porewaters (Cutter, 1992). It is therefore necessary to study the distribution of $\mathrm{Sb}$ species and their redox transformations in order to understand the environmental consequences of their presence in aquatic systems.

Evidence on the association of $\mathrm{Sb}$ species with hydrous oxides of $\mathrm{Mn}$ and $\mathrm{Fe}$ has been shown by adsorption studies (Thanabalasingam and Pickering, 1990) and selective extraction analyses on sediments (Crecelius et al., 1975; Brannon and Patrick, 1985). Iron and manganese oxyhydroxides are ubiquitous components of soils and marine or freshwater sediments. Their oxidizing capacities have already been demonstrated for arsenic (Oscarson et al., 1981; De Vitre et al., 1991) species. In this study, experiments were designed to test the oxidative (and detoxifying) power of amorphous $\mathrm{Fe}$ and $\mathrm{Mn}$ oxyhydroxides on $\mathrm{Sb}$ (III) as a function of time and $\mathrm{pH}$. Since it was our main objective, other factors that could influence the kinetics of oxidation such as temperature and ionic strength were not considered here.

\section{Experimental}

All the reagents used in this study for syntheses, $\mathrm{pH}$ adjustments and measurements were analytical- reagent grade except for $\mathrm{Sb}_{2} \mathrm{O}_{3}$, which was $99.99 \%$ pure.

\subsection{Sampling}

Natural Fe oxyhydroxides were collected from the sediments of Poyang Lake located in the Jiangxi Province (China) using the in situ technique described by Belzile et al., (1989). With this technique, Teflon sheets are inserted in surficial sediments and amorphous iron oxyhydroxides resulting from the upward diffusion and oxidation of ferrous iron present in reducing sediments are collected over a period of 3 to 6 weeks. The studied sediments have been affected by important mining activities of a copper mine located on the Le An River, which flows into Poyang Lake. Natural waters were collected from the Qing River located in Beijing (China) to prepare synthetic Mn oxyhydroxides.

\subsection{Synthetic oxides}

In order to simulate as much as possible the formation of $\mathrm{Fe}$ and $\mathrm{Mn}$ oxyhydroxides under natural conditions (e.g. diffusion of $\mathrm{Fe}(\mathrm{II})$ and $\mathrm{Mn}$ (II) from reducing sediments and oxidation into $\mathrm{Fe}(\mathrm{III})$ - and Mn(IV)-oxyhydroxides at the oxic sediment-water interface), synthetic Fe oxyhydroxides were prepared by dissolving the $\left(\mathrm{NH}_{4}\right)_{2} \mathrm{Fe}\left(\mathrm{SO}_{4}\right)_{2}$ salt in deionized water and allowing the slow oxidation ( $\sim 3$ days) at room temperature of $\mathrm{Fe}$ (II) solutions pre-adjusted at $\mathrm{pH}$ 6.5. This technique should mimic the conditions of natural environments and produce amorphous $\mathrm{Fe}(\mathrm{III})$ oxhyhydroxides and poorly ordered lepidocrocite (Schwertmann and Cornell, 1991; Fortin et al., 1993). Synthetic Mn oxyhydroxides were also obtained by the slow oxidation (15 days) of raw water from the Qing River. Water samples were previously adjusted to $\mathrm{pH} 6.8$ before being spiked with a stock solution of $\mathrm{Mn}\left(\mathrm{NO}_{3}\right)_{2}$. The formation of amorphous Mn oxyhydroxides was accelerated by the presence of manganese-oxidizing bacteria present in natural waters (Diem and Stumm, 1984). In both cases, the added quantities of salt were adjusted to obtain final concentrations of $100 \mathrm{mg} / 1$ of the oxyhydroxides compounds. 


\subsection{Oxidation experiments}

The natural Fe oxyhydroxides collected on Teflon plates were removed from these surfaces and transferred to deionized water. The $\mathrm{pH}$ values of triplicate samples were adjusted to 5.1, 7.2 and 9.0 using $\mathrm{HCl}$ or $\mathrm{NaOH}$ solutions. Similarly, triplicate solutions containing synthetic Fe oxyhydroxides were adjusted to $\mathrm{pH} 5.0,6.0,7.1,8.0,9.1$ and 10.2 , respectively, and solutions containing synthetic $\mathrm{Mn}$ were adjusted to $\mathrm{pH} 6.5,7.5$ and 8.6. The choice of $\mathrm{pH}$ conditions was done to cover most of the natural aquatic systems in which oxyhydroxides can be stable. The colloidal solutions were spiked with an appropriate volume of a $25-\mathrm{mg} / 1 \mathrm{Sb}_{2} \mathrm{O}_{3}$ stock solution. $\mathrm{A} \mathrm{Fe}: \mathrm{Sb}$ molar ratio of 4500 was selected to closely mimic the ratio measured in natural oxyhydroxides collected from Poyang Lake and from other polluted lake sediments (Sudbury, Canada; Belzile et al., unpublished results). All oxidation experiments were conducted at room temperature $\left(20 \pm 3^{\circ} \mathrm{C}\right)$.

At different intervals (1-7 days), $25 \mathrm{ml}$ aliquots of $\mathrm{Fe}$ and $\mathrm{Mn}$ oxyhydroxides suspensions were dissolved in the dark with an equal volume of $0.1 \mathrm{M}$ sodium oxalate at pH 2.2 (De Vitre et al., 1991) and concentrations of $\mathrm{Sb}(\mathrm{III})$ were determined. It was verified previously by spike recovery that the redox state of $\mathrm{Sb}$ was not modified during the dissolution procedure (in the dark) and that $\mathrm{Sb}(\mathrm{III})$ and $\mathrm{Sb}(\mathrm{V})$ could be kept unchanged in the oxalate solution in the absence of light for at least 5 days (see Table 1 and Results and discussion).

\subsection{Analyses}

The concentrations of $\mathrm{Sb}$ (III) and total $\mathrm{Sb}$ as $\mathrm{Sb}(\mathrm{V})$ were measured by adsorptive stripping voltametry (ACSV) using chloranilic acid (2,5-dichloro-3,6-dihydroxy-1,4-benzoquinone) as complexing agent (Wagner et al., 1996; Belzile and Chen., 1999). Voltametric measurements were done on an EG\& G Parc Model 303A connected to a potentiostat/galvanostat Model 263. The working electrode was a hanging mercury electrode and the system was completed by a $\mathrm{Pt}$ auxiliary electrode and a $\mathrm{Ag} / \mathrm{AgCl}$ reference electrode. All measurements were carried out using the differential mode with a $50-\mathrm{mV}$ pulse height, a scan rate of $20 \mathrm{mV} / \mathrm{s}$ and a $5.0-\mathrm{mV}$ scan increment. Samples were deaerated with ultrapure nitrogen for $5 \mathrm{~min}$. For $\mathrm{Sb}(\mathrm{III})$, the $\mathrm{pH}$ was adjusted to $3.0(\mathrm{HCl})$ and the potential was swept from +0.100 to $-0.500 \mathrm{~V}$ after accumulation at +0.100 $\mathrm{V}$ for $5 \mathrm{~min}$. For $\mathrm{Sb}(\mathrm{V})$, the $\mathrm{pH}$ was adjusted to 1.0 . The complex was allowed to stabilize for $10 \mathrm{~min}$ and the potential was swept from -0.500 to $-0.050 \mathrm{~V}$ after a 10 -min deposition time at $-0.500 \mathrm{~V}$. Sb(III) stock solution was prepared by dissolving $\mathrm{Sb}_{2} \mathrm{O}_{3}$ in concentrated $\mathrm{HCl}$ and diluting with double deionized water to obtain a $500-\mathrm{mg} / 1$ solution in $1 \mathrm{M} \mathrm{HCl}$. $\mathrm{Sb}(\mathrm{V})$ stock solution $(500 \mathrm{mg} / \mathrm{l})$ was prepared by dissolving $\mathrm{K}_{2} \mathrm{H}_{2} \mathrm{Sb}_{2} \mathrm{O}_{7} \cdot 4 \mathrm{H}_{2} \mathrm{O}$ in deionized water. Working solutions were prepared daily by appropriate dilution of the stock solutions. For both species, the concentration of chloranilic acid was $5.0 \times 10^{-5}$ M. The detection limits of this technique $(3 \sigma)$ were around $0.5 \mu \mathrm{g} / 1$ for $\mathrm{Sb}(\mathrm{III})$ and $1.0 \mu \mathrm{g} / 1$ for $\mathrm{Sb}(\mathrm{V})$

Table 1

Stability of $\mathrm{Sb}(\mathrm{III})-\mathrm{Sb}(\mathrm{V})$ in the presence of $\mathrm{Fe}$ and $\mathrm{Mn}$ oxyhydroxides dissolved in $0.1 \mathrm{M}$ oxalate solution at $\mathrm{pH} 2.2$

\begin{tabular}{lccccc}
\hline $\begin{array}{l}\mathrm{Sb}(\mathrm{III}) \\
(\mu \mathrm{g} / \mathrm{l})\end{array}$ & $\begin{array}{l}\mathrm{Sb}(\mathrm{V}) \\
(\mu \mathrm{g} / \mathrm{l})\end{array}$ & $\begin{array}{l}\text { Fe oxyhydroxide } \\
(\mathrm{mg} / \mathrm{l})\end{array}$ & $\begin{array}{l}\text { Mn oxyhydroxide } \\
(\mathrm{mg} / \mathrm{l})\end{array}$ & Light & $\begin{array}{l}\text { Recovery of Sb(III) } \\
\text { after } 5 \text { days }( \pm 2 \%)\end{array}$ \\
\hline 50 & 0 & 0 & 0 & yes & 101 \\
50 & 50 & $100^{\mathrm{a}}$ & 0 & yes & 12 \\
50 & 50 & 0 & $100^{\mathrm{b}}$ & yes & n.d. $^{\mathrm{c}}$ \\
50 & 50 & 0 & 0 & no & 101 \\
50 & 0 & $100^{\mathrm{a}}$ & 0 & no & 97 \\
50 & 50 & 0 & $100^{\mathrm{b}}$ & no & 96 \\
30 & 0 & $25^{\mathrm{d}}$ & 0 & no & 99 \\
\hline
\end{tabular}

${ }^{\text {a }}$ Synthetic Fe oxyhydroxides obtained by slow oxidation of $\mathrm{Fe}(\mathrm{II})$.

${ }^{\mathrm{b}}$ Synthetic Mn oxyhydroxides obtained by slow bacterial oxidation of Mn(II).

${ }^{\mathrm{c}}$ Not detectable.

${ }^{\mathrm{d}}$ Natural Fe oxyhydroxides collected from sediments on inert surfaces. 
and the presence of Fe or Mn did not cause significant interferences on the analysis. The concentrations of iron and manganese in natural $\mathrm{Fe}$ oxyhydroxides were determined by colorimetry and atomic absorption spectrometry, respectively (APHA, 1996).

\section{Results and discussion}

It must be stated first that $\mathrm{Sb}$ (III) could not be oxidized by dissolved oxygen alone in the time intervals of our study. Control solutions were systematically measured at each sampling time and no change was noticed in the concentration level of $\mathrm{Sb}$ (III) in the presence or absence of light nor in the presence or absence of oxalate.

\subsection{Stability of $S b(I I I)$ in the oxalate solution}

Because of the effective removal of $\mathrm{Sb}$ (III) from the solution by the strong adsorbents $\mathrm{Fe}$ and $\mathrm{Mn}$ oxyhydroxides at all $\mathrm{pH}$ values covered in this study (Thanabalasingam and Pickering, 1990), it was necessary to dissolve these compounds before measuring $\mathrm{Sb}$ (III). A preliminary experiment was conducted to confirm that the dissolution of the oxyhydroxides compounds would not affect the oxidation state of $\mathrm{Sb}$ adsorbed on their surfaces and that the measured oxidation of $\mathrm{Sb}$ (III) would not be an artefact introduced by the dissolution step. A $0.1-\mathrm{M}$ sodium oxalate solution at $\mathrm{pH} 2.2$ was selected to achieve the dissolution of $\mathrm{Fe}$ and $\mathrm{Mn}$ oxyhydroxides. With this solution, both $\mathrm{Sb}$ (III) and $\mathrm{Sb}(\mathrm{V})$ could remain unchanged for at least 5 days if kept in the dark. The results also indicate that $\mathrm{Sb}$ (III) could be recovered effectively (96-99\%) in the presence of natural or synthetic Fe oxyhydroxides as well as in that of $\mathrm{Mn}$ oxyhydroxides when the dissolution was accomplished in the dark. In the presence of light, however, the oxidation state of $\mathrm{Sb}$ was significantly modified during the dissolution process since only $12 \%$ of the initial amount of Sb(III) could be recovered in the presence of amorphous Fe oxyhydroxides, while $\mathrm{Sb}$ (III) was completely oxidized in the presence of Mn oxyhydroxides (Table 1). Therefore, the dissolution of all samples used in the oxidation experiment was accomplished with the oxalate solution in the dark and all the voltametric analyses were also performed in the dark. The capacity of the oxalate solution to dissolve $\mathrm{Fe}$ and $\mathrm{Mn}$ oxyhydroxides without affecting the oxidation state of adsorbed trace elements had already been exploited in a study on arsenic speciation (De Vitre et al., 1991).

\subsection{Oxidation by natural and synthetic amorphous} Fe oxyhydroxides

A first possible indication that amorphous $\mathrm{Fe}$ oxyhydroxides could oxidize $\mathrm{Sb}$ (III) came from the oxyhydroxides collected from natural sediments. Before any spiking experiments, all Sb present in natural $\mathrm{Fe}$ oxyhydroxides collected from the sediments of Poyang Lake was measured as the oxidized form $\mathrm{Sb}(\mathrm{V})$ and no $\mathrm{Sb}$ (III) could be detected. The average concentration of $\mathrm{Sb}(\mathrm{V})$ measured by differential pulse adsorptive stripping voltametry (DPACSV) in natural Fe oxyhydroxides was $288 \mu \mathrm{g} / \mathrm{g}$ of solid. This represents a natural $\mathrm{Fe}: \mathrm{Sb}$ molar ratio of approximately 4000 if we assume that freshly collected natural $\mathrm{Fe}$ oxyhydroxides were $\mathrm{Fe}(\mathrm{OH})_{3}$. This result could suggest that $\mathrm{Fe}$ oxyhydroxides can effectively oxidize $\mathrm{Sb}(\mathrm{III})$ to $\mathrm{Sb}(\mathrm{V})$ when the former is diffusing from the reducing layers of the sediments along with $\mathrm{Fe}$ (II) and meet the oxidized sediment layer containing amorphous Fe oxyhydroxides.

Results of $\mathrm{Sb}$ (III) oxidation presented in Table 2 clearly shows that amorphous $\mathrm{Fe}$ oxyhydroxides, either natural or synthetic, could effectively convert all $\mathrm{Sb}(\mathrm{III})$ into $\mathrm{Sb}(\mathrm{V})$ in a short period of time. The oxidation of $\mathrm{Sb}$ (III) by synthetic Fe oxyhydroxides can be considered complete after 5 or 6 days. For natural $\mathrm{Fe}$ oxyhydroxides, one or two more days were required to observe the complete transformation of $\mathrm{Sb}(\mathrm{III})$ into $\mathrm{Sb}(\mathrm{V})$. These results suggest that microorganisms present in natural compounds do not play a significant catalysing role in the oxidation process that would rather involve an abiotic transfer of electrons at the surface of Fe oxyhydroxides. The possible overall reaction can be written as:

$$
\begin{aligned}
2 \mathrm{Fe}(\mathrm{OH})_{3}+\mathrm{Sb}(\mathrm{OH})_{3} \rightarrow & 2 \mathrm{Fe}(\mathrm{OH})_{2}+\mathrm{H}_{3} \mathrm{SbO}_{4} \\
& +\mathrm{H}_{2} \mathrm{O}
\end{aligned}
$$

A potential mechanism of the reaction involving (i) the adsorption of antimonite and the formation of 
Table 2

Oxidation of $\mathrm{Sb}$ (III) by $\mathrm{Fe}$ oxyhydroxides as a function of time and $\mathrm{pH}$

\begin{tabular}{|c|c|c|c|c|c|c|c|c|c|c|}
\hline $\begin{array}{l}\text { Type of oxyhdroxide } \\
\text { (adjusted } \mathrm{pH})^{\mathrm{a}}\end{array}$ & $\begin{array}{l}\text { Time } \\
\text { (days) }\end{array}$ & $\begin{array}{l}\% \\
\text { Oxidation }\end{array}$ & $\begin{array}{l}\text { Time } \\
\text { (days) }\end{array}$ & $\begin{array}{l}\% \\
\text { Oxidation }\end{array}$ & $\begin{array}{l}\text { Time } \\
\text { (days) }\end{array}$ & $\begin{array}{l}\% \\
\text { Oxidation }\end{array}$ & $\begin{array}{l}\text { Time } \\
\text { (days) }\end{array}$ & $\begin{array}{l}\% \\
\text { Oxidation }\end{array}$ & $\begin{array}{l}\text { Time } \\
\text { (days) }\end{array}$ & $\begin{array}{l}\% \\
\text { Oxidation }\end{array}$ \\
\hline $\mathrm{S}^{\mathrm{c}}(5.0)$ & 1 & 43 & 2 & 79 & 3 & 85 & 5 & 96 & 7 & $>99$ \\
\hline$S(6.0)$ & 1 & 37 & 2 & 77 & 3 & 89 & 5 & $>99$ & 7 & $>99$ \\
\hline$S(7.1)$ & 1 & 46 & 2 & 87 & 3 & 98 & 5 & $>99$ & 7 & $>99$ \\
\hline$S(8.0)$ & 1 & 41 & 2 & 80 & 3 & 88 & 5 & 98 & 7 & $>99$ \\
\hline$S(9.1)$ & 1 & 44 & 2 & 88 & 3 & 97 & 5 & $>99$ & 7 & $>99$ \\
\hline$S(10.2)$ & 1 & 45 & 2 & 86 & 3 & 93 & 5 & $>99$ & 7 & $>99$ \\
\hline $\mathrm{N}^{\mathrm{d}}(5.1)$ & 1 & 31 & 2 & 64 & 3 & 72 & 5 & 91 & 7 & 96 \\
\hline $\mathrm{N}(7.2)$ & 1 & 32 & 2 & 64 & 3 & 71 & 5 & 90 & 7 & $>99$ \\
\hline $\mathrm{N}(9.0)$ & 1 & 39 & 2 & 78 & 3 & 89 & 5 & 94 & 7 & $>99$ \\
\hline
\end{tabular}

\footnotetext{
${ }^{a}$ Before spiking, the $\mathrm{pH}$ of the slurry solution containing $\mathrm{Fe}$ oxyhydroxides was adjusted using $\mathrm{HCl}$ or $\mathrm{NaOH}$.

${ }^{b}$ The percentage of $\mathrm{Sb}(\mathrm{III})$ oxidation is expressed as: [(1 - measured peak/control peak $\left.) \times 100\right]$, where the control peak is equivalent to the initial spike of $\mathrm{Sb}$ (III). The analytical error associated to the determination of $\mathrm{Sb}(\mathrm{III})$ was around $3 \%$ when the oxidation was $80 \%$ or less and around $2 \%$ when the oxidation was more than $80 \%$.

${ }^{\mathrm{c}}$ Synthetic Fe oxyhydroxides.

${ }^{\mathrm{d}}$ Natural Fe oxyhydroxides.
}

a surface complex with the Fe(III) oxyhydroxide (one $\mathrm{Sb}$ (III) on two Fe(III) sites), (ii) the transfer of two electrons from antimony to two iron atoms, (iii) the release of oxidized antimony (one antimonate for two ferrous iron), and (iv) the release of the reduced $\mathrm{Fe}(\mathrm{II})$ is presented in Fig. 1. The surface complex formed through the adsorption of $\mathrm{Sb}$ (III) on the

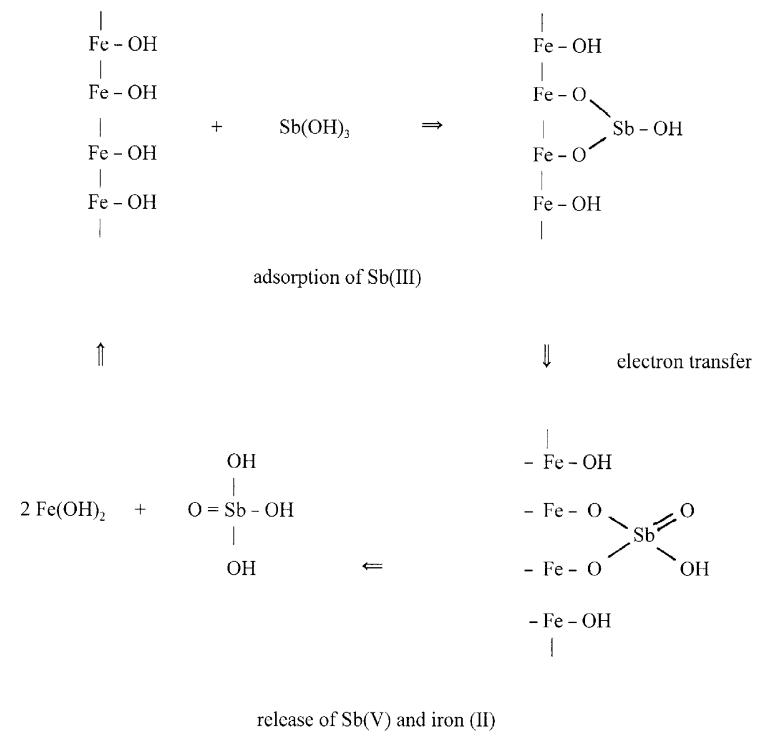

Fig. 1. Schematic representation of the surface reaction involving adsorption of $\mathrm{Sb}(\mathrm{III})$, electron transfer and release of $\mathrm{Sb}(\mathrm{V})$ and $\mathrm{Fe}(\mathrm{II})$ species. oxyhydroxide surface could be inner-sphere (characterized by a largely covalent bond between the metal and the oxygen atoms; Stumm, 1992) if we assume that antimonite appears in solution as the neutral form $\mathrm{Sb}(\mathrm{OH})_{3}$ (Thanabalasingam and Pickering, 1990; Vink, 1996). The released forms of antimonate and iron could differ depending on the solution $\mathrm{pH}$ that affects hydrolysis and dissociation constants. Ultimately, ferrous iron can be re-oxidized by oxygen into ferric iron. For this reason, it was not possible to monitor the release of $\mathrm{Fe}$ (II) into solution but the oxidation reaction could be easily confirmed by measurements of disappearing $\mathrm{Sb}(\mathrm{III})$ and appearing $\mathrm{Sb}(\mathrm{V})$ peaks.

Some oxidation experiments were also conducted in the absence of light to determine if this factor had an influence on the oxidizing capacity of amorphous $\mathrm{Fe}$ and Mn oxyhydroxides or on the oxidation rates. However, no significant differences were observed between the two sets of samples (i.e. presence or absence of light). In both cases, the oxidation was confirmed by the gradual decrease of the $\mathrm{Sb}$ (III) voltametric peak and the corresponding increase of the $\mathrm{Sb}(\mathrm{V})$ peak. In a study on the oxidation of arsenite by synthetic birnessite, Scott and Morgan (1995) observed that As(V) was released into solution as rapidly as As(III) was depleted. The authors suggest that the processes of electron transfer and release of $\mathrm{As}(\mathrm{V})$ are fast compared to the adsorption 
of As(III). A similar statement could be made here for the process involving $\mathrm{Sb}$ (III).

No significant variation of the solution $\mathrm{pH}$ was observed during all oxidation experiments. For both natural and synthetic Fe oxyhydroxides, a slight effect of the solution $\mathrm{pH}$ was generally observed with the oxidation rate being slightly slower under moderately acidic conditions $(<6.0)$. This small decrease in the oxidation rate at low $\mathrm{pH}$ could be attributed to the slightly lower stability of both types of $\mathrm{Fe}$ oxyhydroxides under mild acidic conditions (Stumm and Morgan, 1996). In the $\mathrm{pH}$ range of our study (5.0-10.2), $\mathrm{Sb}(\mathrm{III})$ should exist as $\mathrm{Sb}(\mathrm{OH})_{3}$ (Thanabalasingam and Pickering, 1990; Vink,1996) and the adsorption of this uncharged species should not be strongly affected by the net positive or negative charge on amorphous $\mathrm{Fe}$ oxyhydroxides which have a $\mathrm{pH}_{\mathrm{zpc}}$ of around 8.5 (Stumm, 1992). Therefore, the influence of $\mathrm{pH}$ on the oxidation rate of $\mathrm{Sb}$ (III) should not be related to a difference in its adsorption on Fe oxyhydroxides.

Under the experimental conditions of our study, a pseudo-first order rate law could be tested because of the excess of oxyhydroxide surfaces. As it is indicated in Figs. 2 and 3, linear relationships with good

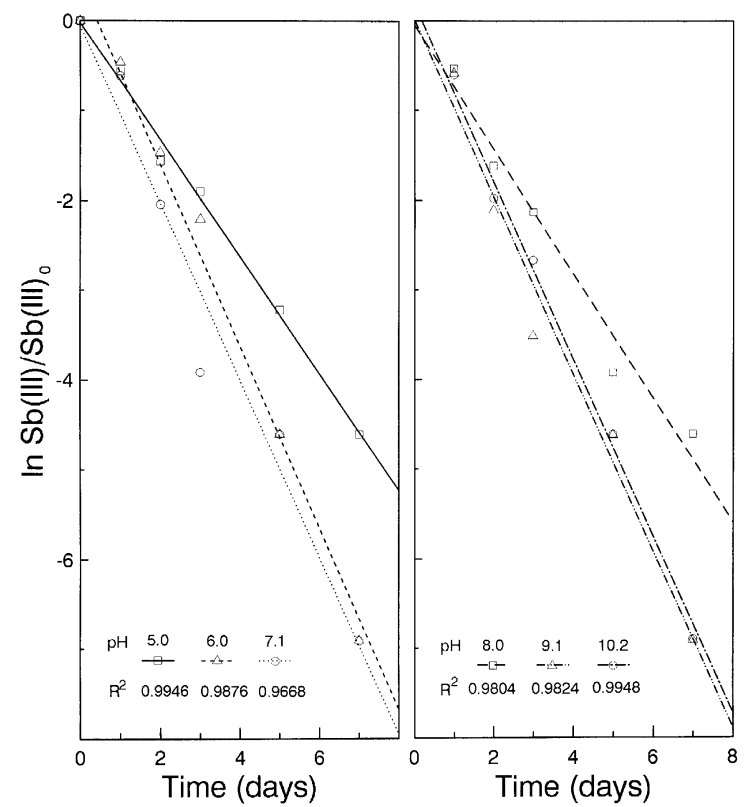

Fig. 2. Pseudo-first order plots showing the oxidation of Sb(III) by synthetic iron oxyhydroxides.

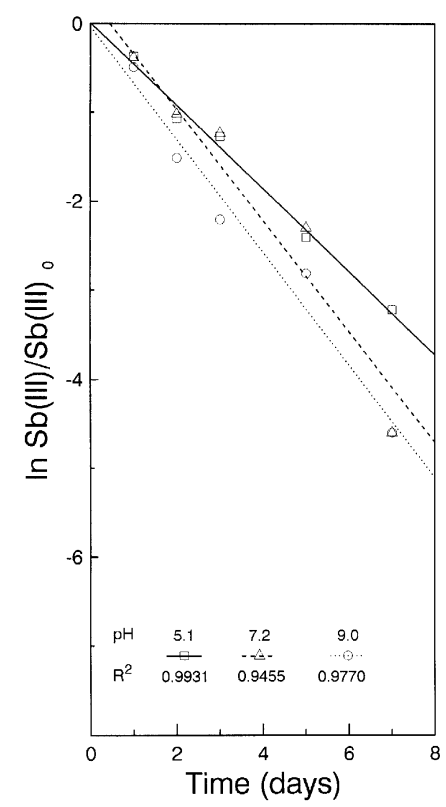

Fig. 3. Pseudo-first order plots showing the oxidation of Sb(III) by natural iron oxyhydroxides.

correlation coefficients indicate that pseudo-first order kinetic rate expressions can be applied to describe the oxidation of $\mathrm{Sb}$ (III) by synthetic and natural amorphous iron oxyhydroxides. Average pseudofirst order rates for synthetic and natural $\mathrm{Fe}$ oxyhydroxides were respectively estimated at $0.887 \pm$ 0.167 day $^{-1}$ and $0.574 \pm 0.093$ day $^{-1}$ (Figs. 2 and 3 ). These estimates are two orders of magnitude higher than the value presented by Cutter (1992) for deep waters of the Black Sea at 0.008 day $^{-1}$. This difference emphasizes the major role played by $\mathrm{Fe}$ oxyhydroxide particles in the oxidation of $\mathrm{Sb}(\mathrm{III})$.

Several factors can explain the difference in the pseudo-first order oxidation rate of $\mathrm{Sb}$ (III) by natural and synthetic Fe oxyhydroxides. One factor could be the difference of crystallinity of the two compounds. Fe oxyhydroxides collected on Teflon surfaces are usually present as ferrihydrite but in acid lakes, a minor fraction can be present as poorly ordered lepidocrocite (Fortin et al., 1993; Tessier et al., 1996). Since, the average $\mathrm{pH}$ value measured in waters overlying Poyang Lake sediments was 5.8, some poorly ordered lepidocrocite could be present with the amorphous forms. Another factor could be the presence of major and minor dissolved elements 
Table 3

Oxidation of $\mathrm{Sb}(\mathrm{III})$ by $\mathrm{Mn}$ oxyhydroxides as a function of time and $\mathrm{pH}$

\begin{tabular}{lllllllll}
\hline $\begin{array}{l}\text { Adjusted } \\
\mathrm{pH}^{\mathrm{a}}\end{array}$ & $\begin{array}{l}\text { Time } \\
(\mathrm{h})\end{array}$ & $\begin{array}{l}\% \\
\text { Oxidation }^{\mathrm{b}}\end{array}$ & $\begin{array}{l}\text { Time } \\
(\text { days })\end{array}$ & $\begin{array}{l}\% \\
\text { Oxidation }^{\mathrm{b}}\end{array}$ & $\begin{array}{l}\text { Time } \\
(\text { days })\end{array}$ & $\begin{array}{l}\% \\
\text { Oxidation }^{\mathrm{b}}\end{array}$ & $\begin{array}{l}\text { Time } \\
(\text { days })\end{array}$ & $\begin{array}{l}\% \\
\text { Oxidation }^{\mathrm{b}}\end{array}$ \\
\hline 6.5 & 12 & 30 & 1 & 55 & 2 & 88 & 3 & $>99$ \\
7.5 & 12 & 41 & 1 & 68 & 2 & $>99$ & 3 & $>99$ \\
8.6 & 12 & 50 & 1 & 87 & 2 & $>99$ & 3 & $>99$ \\
\hline
\end{tabular}

\footnotetext{
${ }^{\mathrm{a}}$ Before spiking, the $\mathrm{pH}$ of the slurry solution containing $\mathrm{Mn}$ oxyhydroxides was adjusted using $\mathrm{HCl}$ or $\mathrm{NaOH}$.

${ }^{b}$ The percentage of $\mathrm{Sb}$ (III) oxidation is expressed as: [ $(1-$ measured peak/control peak $\left.) \times 100\right]$, where the control peak is equivalent to the initial spike of $\mathrm{Sb}(\mathrm{III})$. The analytical error associated to the determination of $\mathrm{Sb}$ (III) was around $3 \%$ when the oxidation was $80 \%$ or less and around $2 \%$ when the oxidation was more than $80 \%$.
}

incorporated by natural oxyhydroxides during their formation (Belzile et al., 1989; Tessier et al., 1996). The presence of already adsorbed elements and the difference in crystallinity could reduce the adsorbing capacity of natural oxyhydroxides when they are compared to synthetic compounds. Finally, natural Fe oxyhydroxides will also contain natural organic matter in the forms of humic and fulvic acids sorbed on their surfaces as well as bacterial remains and exocellular polymers (Fortin et al., 1993; Tessier et al., 1996). Adsorbed organic compounds can slightly influence adsorptive and oxidative properties of natural oxyhydroxides.

The concentration of $\mathrm{Mn}$ present in natural $\mathrm{Fe}$ oxyhydroxides was determined after the dissolution in the oxalate buffer. An average concentration of $5.3 \pm 0.6 \mathrm{mg}$ of $\mathrm{Mn} / \mathrm{g}$ of $\mathrm{Fe}$ oxyhydroxides was measured, indicating that the proportion of Mn oxyhydroxides in the $\mathrm{Fe}$ deposits did not represent more than $0.6 \%$ of the total. This Mn was more probably present as an adsorbed species since the low $\mathrm{pH}$ of overlying waters (5.8) could not favour the formation of distinct Mn oxyhydroxides (Belzile et al., 1989). This suggests that the oxidation of $\mathrm{Sb}(\mathrm{III})$ by natural Fe oxyhydroxides was real and did not result from the possible presence of natural Mn oxyhydroxides in the $\mathrm{Fe}$ deposits.

\subsection{Oxidation by synthetic amorphous Mn oxyhy- droxides}

For the three tested $\mathrm{pH}$ values, the oxidation of $\mathrm{Sb}$ (III) by synthetic Mn oxyhydroxides (Table 3) was very rapid and completed after only 3 days, demonstrating a more efficient oxidizing capacity of
Mn oxides compared to Fe oxyhydroxides. The possible overall reaction can be written as:

$\mathrm{MnO}_{2}+\mathrm{Sb}(\mathrm{OH})_{3}+\mathrm{H}_{2} \mathrm{O} \rightarrow \mathrm{Mn}(\mathrm{OH})_{2}+\mathrm{H}_{3} \mathrm{SbO}_{4}$.

A potential mechanism similar to the one described for iron oxyhydroxides would also involve (i) the adsorption of antimonite and the formation of a surface complex with the manganese(IV) oxide

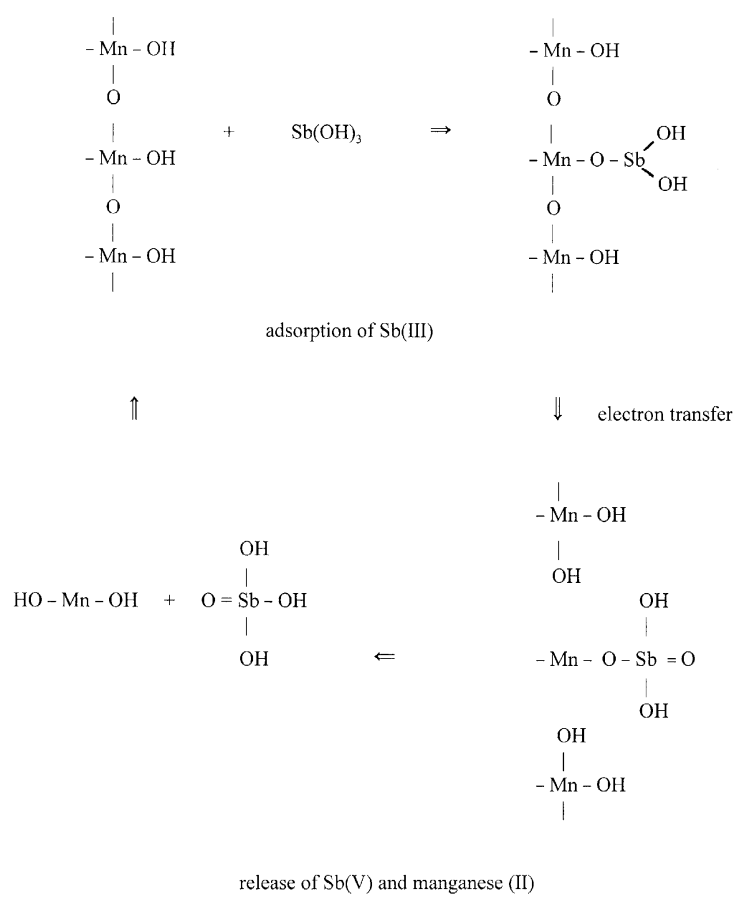

Fig. 4. Schematic representation of the surface reaction involving adsorption of $\mathrm{Sb}(\mathrm{III})$, electron transfer and release of $\mathrm{Sb}(\mathrm{V})$ and $\mathrm{Mn}(\mathrm{II})$ species. 


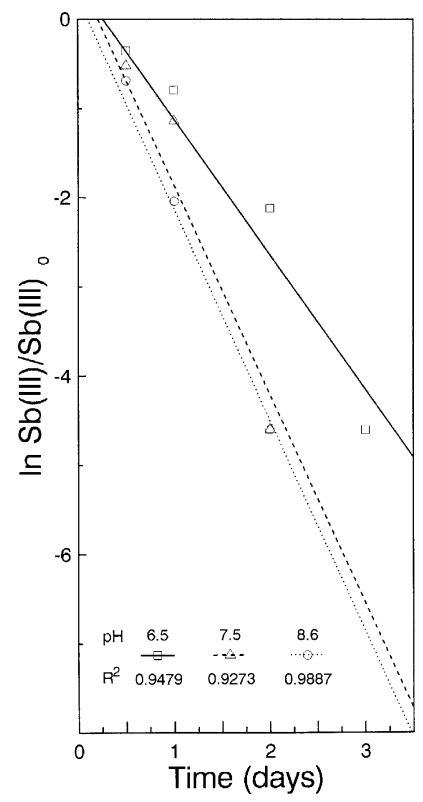

Fig. 5. Pseudo-first order plots showing the oxidation of $\mathrm{Sb}$ (III) by synthetic manganese oxyhydroxides.

(one $\mathrm{Sb}$ (III) on one Mn site), (ii) the transfer of two electrons from antimony to manganese, (iii) the release of the oxidized antimony (one antimonate for each manganese (II)), and (iv) the release of the reduced Mn(II) as presented in Fig. 4. The influence of $\mathrm{pH}$ observed for $\mathrm{Fe}$ oxyhydroxides was also noticeable here with a slightly slower pseudo-first order oxidation rate at $\mathrm{pH} 6.5$ which was estimated at 1.52 day $^{-1}$ compared to 2.35 day $^{-1}$ at $\mathrm{pH} 7.2$ and 9.0 (Fig. 5). The difference can also be attributed to the lower stability of Mn oxyhydroxides below pH 7 . The presence or absence of light did not affect the pseudo-first order oxidation rate. Since the initial synthesis of Mn oxyhydroxides involved natural water containing bacteria, the influence of microorganisms on the kinetics of oxidation could not be determined.

\subsection{Geochemical and environmental implications}

The results of this study suggest that the toxic inorganic antimonite present in anoxic aquatic systems can be rapidly adsorbed and oxidized by $\mathrm{Fe}$ and Mn oxyhydroxides into the less toxic $\mathrm{Sb}(\mathrm{V})$ during its transport to the oxic environment. For instance, the presence of toxic $\mathrm{Sb}$ (III) in anoxic interstitial waters and its eventual diffusion across the oxic layer of sediments where Fe and/or Mn oxyhydroxides are usually abundant could rapidly lead to a natural detoxification of the water through this oxidation process. The same oxidizing and detoxifying power of amorphous $\mathrm{Fe}$ and $\mathrm{Mn}$ oxyhydroxides has already been observed for arsenic (Oscarson et al., 1981; De Vitre et al., 1991). Our results also suggest that considering only the oxidized form antimonate in studying the adsorption of inorganic $\mathrm{Sb}$ on natural Fe and Mn oxyhydroxides should be acceptable since the $\mathrm{Sb}$ (III) can rapidly be transformed into $\mathrm{Sb}(\mathrm{V})$ in their presence.

\section{Acknowledgements}

Financial support from the Chinese Academy of Sciences and the Natural Sciences and Engineering Research Council of Canada is acknowledged. The manuscript greatly benefited from the critical comments of Pat Brady and Greg Cutter.

\section{References}

Andreae, M.O., Asmode, J.F., Foster, P., Van't dack, L., 1981. Determination of antimony (III), antimony (V), and methylantimony species in natural waters by atomic absorption spectrometry with hydride generation. Anal. Chem. 53, 1766-1771.

Andreae, M.O., Froelich Jr., P.N., 1984. Arsenic, antimony, and germanium biogeochemistry in the Baltic Sea. Tellus 36, $101-117$.

APHA (American Public Health Association), 1996. Standard Methods for the Examination of Water and Wastewater. 16th edn., Washington, DC.

Belzile, N., De Vitre, R.R., Tessier, A., 1989. In situ collection of diagenetic iron and manganese oxyhydroxides from natural sediments. Nature 340, 376-377.

Belzile, N., Chen, Y.-W., 1999. Analytical procedure for the determination of antimony(III) and total antimony in amorphous iron and manganese oxyhydroxides. Can. J. Anal. Sci. Spectrosc. 44, 85-88.

Boyle, R.W., Jonasson, R., 1973. The geochemistry of arsenic and its use as an indicator element in geochemical prospecting. $\mathrm{J}$. Geochem. Explor. 2, 251-296.

Brannon, J.M., Patrick Jr., W.H., 1985. Fixation and mobilization of antimony in sediments. Environ. Pollut., Ser. B 9, 107-126.

Crecelius, E.A., Bothner, M.H., Carpenter, R., 1975. Geochemistries of arsenic, antimony, mercury, and related ele- 
ments in sediments of Puget Sound. Environ. Sci. Technol. 9, 325-333.

Cutter, G.A., 1992. Kinetic controls on metalloid speciation in seawater. Mar. Chem. 40, 65-80.

Cutter, G.A., Cutter, L.S., 1995. Behavior of dissolved antimony, arsenic, and selenium in the Atlantic Ocean. Mar. Chem. 49, 295-306

De Vitre, R.R., Belzile, N., Tessier, A., 1991. Speciation and adsorption of arsenic on diagenetic iron oxyhydroxides. Limnol. Oceanogr. 36, 1480-1485.

Diem, D., Stumm, W., 1984. Is dissolved $\mathrm{Mn}^{2+}$ being oxidized by $\mathrm{O}_{2}$ in absence of Mn-bacteria or surface catalysts? Geochim. Cosmochim. Acta 48, 1571-1573.

Fortin, D., Leppard, G.G., Tessier, A., 1993. Characteristics of lacustrine diagenetic iron oxyhydroxides. Geochim. Cosmochim. Acta 57, 4391-4404.

Gurnani, N., Sharma, A., Talukder, G., 1994. Effects of antimony on cellular systems in animals - a review. Nucleus 37 , 71-96.

Maeda, S., 1994. Safety and environmental effects. In: Patai, S. (Ed.), The Chemistry of Organic Arsenic, Antimony and Bismuth Compounds. Wiley, New York, pp. 725-759.

Middelberg, J.J., Hoede, D., Van Der Sloot, H.A., Van der Weijden, C.H., Wijkstra, J., 1988. Arsenic, antimony and vanadium in the North Atlantic Ocean. Geochim.Cosmochim. Acta 52, 2871-2878.

Nriagu, J.O., 1989. A global assessment of natural sources of atmospheric trace metals. Nature 338, 47-49.

Nriagu, J.O., Pacyna, J.M., 1988. Quantitative assessment of worldwide contamination of air, water and soils by trace metals. Nature 333, 134-139.

Oscarson, D.W., Huang, P.M., Defosse, C., Herbillon, A., 1981.
Oxidative power of $\mathrm{Mn}$ (IV) and $\mathrm{Fe}(\mathrm{III})$ oxides with respect to As(III) in terrestrial and aquatic environments. Nature 291, 50-51.

Ragaini, R.C., Ralston, H.R., Roberts, N., 1977. Environmental trace metal contamination in Kellogg, Idaho, near a lead smelting complex. Environ. Sci. Technol. 11, 773-781.

Schwertmann, U., Cornell, R.M., 1991. Iron Oxides in the Laboratory: Preparation and Characterization. $\mathrm{VCH}$ Verlagasgellschaft.

Scott, M.J., Morgan, J.J., 1995. Reactions at oxide surfaces: 1. Oxidation of As(III) by synthetic birnessite. Environ. Sci. Technol. 29, 1898-1905.

Stumm, W., 1992. Chemistry of the Solid-Water Interface. Wiley-Interscience, New York.

Stumm, W., Morgan, J.J., 1996. Aquatic Chemistry. 3rd edn. Wiley-Interscience, New York.

Tessier, A., Fortin, D., Belzile, N., De Vitre, R.R., Leppard, G.G., 1996. Metal sorption to diagenetic iron and manganese oxyhydroxides and associated organic matter: narrowing the gap between field and laboratory measurements. Geochim. Cosmochim. Acta 60, 387-404.

Thanabalasingam, P., Pickering, W.F., 1990. Specific sorption of antimony (III) by the hydrous oxides of $\mathrm{Mn}, \mathrm{Fe}$, and $\mathrm{Al}$. Water, Air, Soil Pollut. 49, 175-185.

Vink, B.W., 1996. Stability relations of antimony and arsenic compounds in the light of revised and extended Eh-pH diagrams. Chem. Geol. 130, 21-30.

Wagner, W., Sander, S., Henze, G., 1996. Trace analysis of antimony (III) and antimony (V) by adsorptive stripping voltametry. Fresenius' J. Anal. Chem. 354, 11-15.

Wedepohl, K.H., 1995. The composition of the continental crust. Geochim. Cosmochim. Acta 59, 1217-1232. 